\title{
Low Back Pain: A Comprehensive Review on the Diagnosis, Treatment Options, and the Role of Other Contributing Factors
}

\author{
Shahul Hameed Pakkir Mohamed ${ }^{1}$, Mohamed Ali Seyed ${ }^{2 *}$ (ID \\ ${ }^{1}$ Department of Physical Therapy, Faculty of Applied Medical Science, University of Tabuk, Tabuk, Kingdom of \\ Saudi Arabia; ${ }^{2}$ Department of Biochemistry, Faculty of Science, University of Tabuk, Tabuk, Kingdom of Saudi Arabia
}

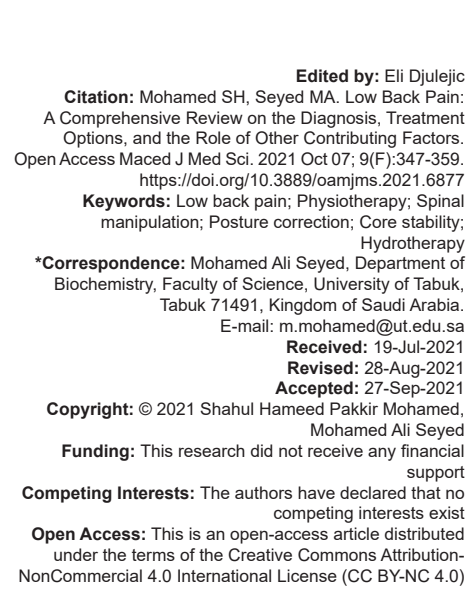

Introduction

Low back pain is a growing global chronic problem, which normally affects musculoskeletal system [1] and accounts for huge healthcare spending for affected individuals, mostly elderly people and indirectly for nations around the world on their healthcare expenditure [2]. Until now, a structured physical exercise regimen or timely interventions on issue basis are highly recommended as an effective management for persistent long-term LBP; however, recent investigations have shown that the exercise regimen has lessen the pain temporarily or decreasing pain for the moment only [3], [4]. On the other hand, this physical activity-oriented intervention specifically reduces the risks involved among chronic LBP cases but these options were not acceptable to pain therapists. The reasons are unknown or not clear till now, why these physical activities related preventive strategies failed to alleviate chronic LBP and associated economic burdens and disability [5].
Back pain (BP) is broadly classified into three major categories. They are characterized as acute one if it lasts for 6 weeks or less than that duration, sub-acute condition is ranging between 6 weeks to 3 months period, whereas the chronic pain is measured if it persists more than 3 months period [6]. Back pain is normally viewed as persistent chronic problem mostly affects elderly people (80\%) and have huge impact on their day today activities. However, in recent years, it is viewed as an uprising devastating condition among technocrats working in the information technology (IT) and BPO sectors and bring direct and indirect loss of economy as well as quality of life but exists in their life for some duration [7], [8], [9], [10]. To support this, numerous contributing factors are identified and proposed for rapid origin of pain such as muscle sprain and strain, which are instigated by any type of accidents, longer sitting hours, and weight lifting activities [11]. Besides the above, numerous disease conditions such as scoliosis, osteoporosis, and arthritis or other circumstances may also contribute to the formation of LBP [6]. However, after thorough assessment and evidence on causes 
and reasons, medical practitioners in this field suggest/ recommend either surgery or other therapeutic options to combat LBP, which include chronic types of pain [11].

It is well established that LBP is widely viewed as a common problem that brings the affected persons to pain professionals [6]. In this regard, numerous therapeutic options are available for LBP, which are extremely valuable when it is employed together with other standard adjuvant therapeutic modalities employed by well-trained medical professionals who are an expert in analyzing affected persons anatomy and physiology of pain [12]. Besides the above, pain managing experts are currently equipped with the necessary skills to alleviate the LBP by employing delicate advanced methods and procedures. However, for various reasons, the above measures failed to bring success in the form of therapeutic as well as other forms of intervention by a patient for LBP can have several variables [10].

Although the management of LBP both in terms of diagnosis as well as the therapeutic options has witnessed considerable progress, challenges are still existing not only within countries but also in the regions and continents [12]. Despite these challenges, steady growth has been made in understanding of BP and related contributing factors like social, psychological and genetics. These new knowledge with technology advancements have provided motivation for the development of new diagnostic procedures, evidence-based screening methods and more targeted interventions, which underline the necessity for a multidisciplinary approach to the management of LBP that integrates not only biological but also psychological and social aspects [13].

Hence, in the present article, we comprehensively review and discuss about LBP and its associated pathophysiology, diagnosis, and available treatment options. This review highlights the role of genetic factors that specifically modify intervertebral disc stability and pain signaling that may independently impact on the risk of developing chronic BP and also explores the evidence and current therapeutic options available and benefits associated with non-surgical options for LBP. In addition, this review broadly addresses risks and contributing factors associated with acute and persistent LBP; response and recovery options employed and finally focused on new innovative physical activity-oriented efficacy if any in pain management specifically for aged population.

\section{Genetic Contributions in LBP}

The demonstration of LBP is predisposed by either structural, psychosocial, or professional factors [14]. Besides, additional factors such as biochemical and inflammation also contribute to the evolution of acute toward chronic pain, more importantly genetic or hereditary factors may influence on any of these contributing factors [15]. In line with this, recent investigations have been largely engaged on genes which determine bone and cartilage structures, which are demonstrated by morphological signs using magnetic resonance imaging (MRI) [16]. The following signs were found to be associated with genetic contributions like disc height narrowing, disc herniation [17], [18], and various other descriptions related to LBP, which include duration of severe episode of LBP and related hospitalizations associated. However, the estimates for these heritability variables for LBP vary ranging from 30 to $45 \%$ [16].

Although, till now, only few genetic influences were caused by genes, which affect disc degeneration suggests that genes involved in pain perception, signaling, and psychological processing [19], and genetic variants of immune genes [20], [21] contribute to the proportion of heritability of chronic BP. The genetic variability in pain signaling pathways contributes to the variance in pain sensitivity and the individual response to treatment strategies [19].

\section{Diagnostic Approaches Employed in Pain}

The current diagnostic tools generally aimed at focusing on LBP affected patients of both specific as well as non-specific cases [12]. Specific low back pain (SLBP) is generally characterized by multiple symptoms like various types of fractures, infections and bone, and joint problems exhibited by the affected patients, which is evident by reports of multiple clinical investigations [12]. On the other hand, non-specific low back pain (NLBP) is defined by signs or symptoms elicited without any particular cause, normally by unknown or non-specific origin [22]. Nearly $90 \%$ of NLPB patients' symptoms were characterized in the clinical settings based on diagnosis with the exclusion of specific pathology [23], [24].

Although various diagnostic as well as therapeutic strategies are currently adopted for managing NLBP, the following approaches [24], [25], [26], [27] are employed by general practitioners such as lumbago, physiotherapists focus on hyperextension and chiropractors' faces joint problems and finally, orthopedic surgeons' focal point is degenerative disc issues [24], [26]. Although, we have to admit that at present there are no unique and reliable classifying systems exist for majority cases of NLBP, in the clinical practice as well as highlighted in various literatures, NLBP is still viewed as the existence of the complaints [24], [28]. 


\section{Role of Advanced Therapeutic Approaches in the Management of Pain}

Based on the above fact, it is necessary and required to introduce various advanced techniques available in the healthcare settings such as fluoroscopy technique that may revolutionize various novel interventional therapeutic options for long persistent pain by providing superior precision to the needle position [12] or by employing newly available digital subtraction angiography imaging technique or unintended intrathecal placements of needles may avert death in the form of injury to the intra-spinal structures like, nerve roots, blood vessels and spinal cord [29], [30]. Although, most of BP conditions do not require surgery as an option because various other modes of therapeutic options such as home remedies or by employing alternative medicines and changes in personal lifestyles may improve or alleviate back pain related complications as these options may provide temporary relief until the person may opt for other permanent therapeutic choices which include surgical procedures [25], [29].

\section{Alternative Therapeutic Options and their Role in the Management of Pain}

Although, LBP management differs from person to person, it is not logic to expect that all patients will respond to the same treatment approach, and no single therapeutic intervention is generally completely effective for all patients. Consequently, limited studies are used to manage the pain of one or more interventions guided by evidence and efficacy, while aiming to reduce overall costs [31], [32]. Pharmacological therapies, physical and rehabilitation treatments, psychiatric treatments, complementary and alternative medicine approaches, and percutaneous approaches that are minimally invasive are relevant courses of care. The overview of the pain management specifically both acute and chronic LBP is explained in Table 1.

\section{Spinal Manipulation}

Spinal manipulation (SM) is otherwise called spinal manipulative therapy or manual therapy [33] (Figure 1). SM technique is extensively used for the treatment of LBP and has been recognized in several randomized controlled trials. The aim of this technique is to relieve pressure on the joints, reducing inflammation, and enhancing nerve function. The fact that they achieve a pop or cracking sound inside
Table 1: Management of Acute LBP (without serious pathology)

- Initial reassurance, advice on staying active and avoiding bed rest, and self-

management advice.

- Self-management for low back pain can include self-exercises and information from reading pamphlets or participating in online education.

- Therapeutic exercises, superficial heat, Kinesio taping, and manual therapy are some of the most common conservative physical treatments.

- Recommendations for returning to normal activities or a referral to an individual or group therapy program.

- For short period of time, pharmacological treatments including nonsteroidal antiinflammatory medications (NSAIDs) and mild opioids are recommended (paracetamol is not recommended).

- In 7-14 days, the progress should be reviewed.

Management of Chronic LBP (without serious pathology)

- A clinical assessment (patient history, physical or clinical examination, and neurological

tests - to recognize radicular features) is used to triage patients.

- To rule out significant pathologies, patients should be checked for "red flags," and diagnostic tests (such as imaging) should only be performed if they are suspected.

- To predict poor outcomes, patients should be assessed for psychosocial risk factors ('yellow flags' such as low self-efficacy, fear of movement, and catastrophizing).

- Education and self-management, as well as the resumption of normal activities and exercise, are indicated as non-pharmacological and non-invasive management treatments, with the addition of psychosocial programs for individuals whose symptoms persist (multidisciplinary treatments)

-Walking, yoga, tai chi, Pilates, and progressive relaxation are some of the most used conservative physical treatment routines (manual therapy, relaxation techniques, massage, in some guidelines).

- There is no evidence that one sort of exercise is better than another

- Patients' preferences and the treating therapist's experience may influence the final decision.

- Passive physical therapy (spinal mobilization, massage, acupuncture, and spinal manipulation) is rarely recommended, or in some guidelines, is optional.

- Passive approaches (rest and drugs) are associated with worsening disability, and are not recommended.

- Nonsteroidal anti-inflammatory medicines (NSAIDs) and antidepressants, if needed should be used at the lowest effective dose and for the shortest time possible.

- Denervation techniques, injections, and surgical procedures are generally discouraged.

- If there is no improvement after four weeks, or if pathology or radiculopathy is suspected, an orthopedic specialist should be consulted.

synovial joints is the key feature of SM techniques. The explanation for this audible release is subject to some debate, but it is generally agreed to reflect a spinal facet joint cavitation [34]. A systematic analysis concluded that it is clinically better than sham therapy in the terms of reducing short-term pain and disability from chronic LBP [35]. The mode of action can be classified into biomechanical, neurophysiological, and psychological aspects. The thoughts behind the SM cause biomechanical variations within the spine, which in turn cause physiological changes.

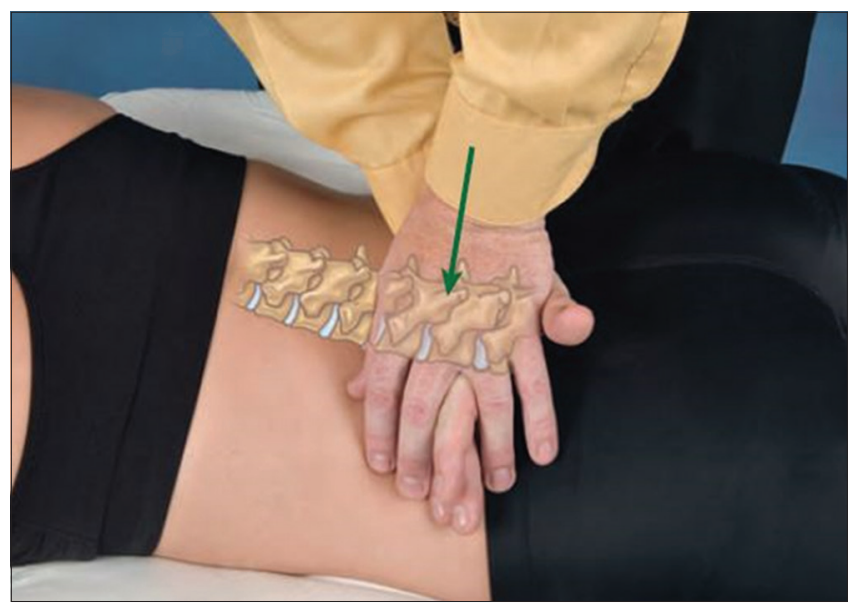

Figure 1: Demonstrates spinal manipulation and illustrate the central anterior glide with pisiform contact

It is expected that it can influence the amount and type of sensory input obtained by the central nervous 
system (CNS). This is because the SM activates the organs of the Golgi tendon and afferent muscle spindle. $\mathrm{SM}$ is also believed to change the excitability of motor neurons and affect reflex neural outputs [36]. SM, in addition, has a psychological effect on patients. It was found in a systematic analysis that SM enhanced pain and psychological effects relative to verbal treatments [37]. In a current systematic review and meta-analysis examining the impact of SM and mobilization on the cardiovascular parameter, it was shown that spinal manipulation and mobilization could significantly reduce systolic and diastolic blood pressure [38]. A common intervention administered in patients with LBP is SM to the lumbar spine. Sixty- three percent of 984 LBP patients registered immediate pain improvements following SM [39]. Manipulations have also been suggested to have shown better results when researching and measuring experimentally induced pain compared to exercise, education, and other treatment measures [40].

\section{Acupuncture}

Manual Acupuncture (MA) is one of the most commonly used treatment methods in Traditional Chinese Medicine (TCM) [41], which is mainly used for a variety of pain and other disorders. Acupuncture has been described as a treatment technique involving one or more needles entering the skin without an injection [42]. The physiological effects of needling in particular body points are thought to be characterized by the activation of endogenous pain control mechanisms [43]. The dorsal horn, which can trigger or inhibit those points on the body that induce the release of opioids including serotonin and catecholamine, is inhibited by this technique [44], [45]. These neurotransmitters have different effects, such as anti-inflammatory, analgesics, muscle relaxants, and antidepressant effects [43]. Electroacupuncture (EA) is another form of acupuncture that uses an electric current to enhance the effects of the needles [46]. Low frequencies are commonly recommended when using electro-acupuncture in patients with LBP to achieve a quicker analgesic and anesthetic than conventional manual acupuncture, as shown by the physiological reaction [47]. Furthermore, the effects of a standardized amount and quality of stimulation, which can be accomplished by controlling the duration and range of the input current, can be helpful for pain in general [48].

\section{Weight Loss}

Weight reduction is commonly prescribed in people with spinal pain who are overweight or obese as a therapeutic strategy to reduce pain and disability [49]. Obesity has been a worldwide epidemic in recent years. Obese subjects are commonly categorized by musculoskeletal disorders and particularly by Chronic NLBP. Inactivity exacerbates LBP pathology, weight gain, and physical deconditioning, which is a major concern for LBP [50]. Inactivity decreases intervertebral discs space and increases the content of paraspinal muscle fat, the severity of pain, and the level of disability [51]. Clinically, several exercise plans for LBP have been reviewed, but few have focused on overweight people or Quality of Life (QOL) outcomes. Isolated therapeutic exercises [52], [53], manual therapies [54], [55], [56] and exercise with integrated therapies (cognitive behavioral therapy, alternative therapies, and nutrition) [55], [57], [58], [59] are among the several programs examined. A sedentary lifestyle triggers an increase in LBP, deconditioning, anxiety avoidance, and functional limitations [60]. By enhancing pain symptoms, physical activity, and fearavoidance behaviors, regular exercise may help to break the cycle [61], [62]. As self-efficacy and health development, longer-lasting participation exercises will increase energy expenditure and activity levels [63]. The better results of controlling the LBP are QOL and perceptions of functionality [64], [65].

Physicians face a daunting challenge when it comes to prescribing exercise to help this population overcome LBP and participate in everyday activities [64]. While studies indicate that various exercise strategies improve health outcomes in overweight people with LBP, their efficacy outside of the clinical study setting is uncertain due to personal costs, stigma, and a lack of access to facilities or trainers. In the successful recovery of obese patients with a number of chronic pain problems, lifestyle modification remains a core instrument. Such interventions include educating the obese subjects on the importance of diet, weight loss, behavior changes, and modifying the level of physical activity [62].

\section{Anti-inflammatory Drugs}

Nonsteroidal anti-inflammatory (NSAIDs) drugs are also commonly used first-line analgesic agents for LBP treatment. Both acute and chronic LBP requires pharmacological care. For short-term relief, acetaminophen, and NSAIDs have been shown to be effective [66], [67], [68]. At doses up to 4 g/day, acetaminophen does not display a significant difference in analgesia for acute pain as compared to NSAIDs. Although, for pain relief, acetaminophen is significantly lower than NSAIDs for CLBP [69]. Non-selective and COX-2 selective NSAIDs have also been shown to be more effective than placebo in acute and chronic LBP, 
with no significant difference in efficacy between the two types of NSAIDs [68], [70]. Because of the risk of systemic renal, cardiovascular, and gastrointestinal side effects, it is recommended that NSAIDs be used at the lowest effective dose for the shortest time possible [69], [70]. Skeletal muscle relaxants for acute LBP have also been shown to be successful. Analgesia is preferable to placebo in two-week trials, but there is no clear distinction between specific muscle relaxants [67] [70].

\section{Posture Correction}

Poor posture and long hours of sitting are the risk factors of LBP, including lumbar disc degeneration and herniation, arthritis, cervical spur, and spinal deformity [71]. While sitting, the average individual's thighs and torso form a nearly 90-degree angle and the pelvis tilts backward in a sitting position and forward in a standing position [72], [73], [74]. Slouched posture can cause the effect of function in the digestive and respiratory systems, reduce the space of the chest and abdomen, and contribute to an unbalanced body which leads to LBP [75]. Evidence indicates that many people experience signs of perceived body discomfort during prolonged sitting, especially in the buttock and lower back regions. Discomfort has contributed to increased muscle fatigue during prolonged sitting, decreased intervertebral disc space, nutrition, and decreased muscle oxygen and blood flow [70]. In contrast with other sitting postures, prolonged sitting in the forward-leaning position substantially increased pain in the lower back region [76]. There are many treatments approaches available today for the control of LBP, such as posture correction, manual therapy, exercise therapy, electrotherapy, patient education, and ergonomic modifications [75]. In everyday life, habitual inappropriate posture with low muscle activity influences both the volume and strength of the lumbar muscle [71], [73]. Thus, exercise programs are effective in reducing pain and discomfort, enhancing physical function, and increasing individuals' oxygenation and blood flow to the lower back [75].

Besides, prolonged inactivity is also known to contribute to a reduction in muscle strength, spinal flexibility, and QOL. Previous research has shown that $40-64 \%$ of people subjected to have LBP during prolonged standing, even though they do not have it before [77]. Long periods of standing require the back extensors to stay engaged for an extended period of time, which can lead to muscle fatigue [78]. Excessive metabolic waste development and accumulation as a result of prolonged static contraction may cause fatigue [79]. Many treatments strategies, such as stretching exercises, muscle strengthening, and flexibility training may have a significant positive impact on posture. In addition to that, several CLBP postural rehabilitation methods, such as the Global Postural Rehabilitation (GPR) process, are focused on muscular kinetic chains, while others, such as the McKenzie (MK) method is based on biomechanical approaches [80], [81], related to the structure of the lumbar intervertebral disc (IVDP) during flexion and extension movements. The American College of Physicians' guidelines specifically link good efficacy of Tai-chi exercises, Pilate's method, and Yoga postures to therapeutic exercise recommendations; the Nice guidelines also recommend the MK method, core stability exercises, hydro-kinesiotherapy, the Feldenkrais method, and aerobic exercises, while the Alexander method appears to be efficient [82], [83]. All the above treatment methods are supporting postural correction methods either directly or indirectly.

\section{Core Stability Exercise}

In recent years, several clinical trials focusing on core stability exercise and lumbopelvic stabilization programs have been performed, with the majority of them indicating that exercise therapy is superior to any other treatment for CLBP (such as Spinal Mobilization, conservative physical therapy treatment, advice to stay active movement, and no treatment) in reducing pain, increasing muscle strength, post-treatment impairment, and long-term function [84], [85], [86], [87]. In core stabilization exercises, Rectus and Transversus abdominis (TrA), lumbar multifidi, and other abdominal, diaphragmatic, paraspinal, and pelvic muscles are targeted. Different studies in patients with CLBP have been reported delayed activation of TrA with respect to erector spinae with severe multifidus atrophy [88]. It was first proposed that spine instability is likely to be caused by any dysfunction of the structures of either spinal passive (non-contractile) or active (trunk muscles) or by decreased neural control over these two sections, and that instability could lead to LBP. Spine instability may cause excessive strain of the tissue and lead to pain. Panjabi assumed that the trunk muscles should be actively contracted to compensate for the lack of passive stabilization. It has been shown that muscle cocontraction improves trunk stability [89].

\section{Transcutaneous Electrical nerve Stimulation (TENS)}

Therapeutic treatment of LBP patients is challenging [90]. Pharmacological therapy is routinely 
prescribed to minimize the effect of LBP on the everyday lives of individuals. However, inappropriate and non-optimal drug prescribing is common [91], [92]. Non-pharmacological therapy, such as hot packs, and transcutaneous electrical nerve stimulation (TENS) can help these patients [93], [94]. TENS is a cost-effective method of treatment that delivers electrical impulses through the skin. TENS stimulates a diverse neuronal network that activates downward inhibitory systems, minimizing hyperalgesia [95], [96]. There is growing evidence that sensitized central pain mechanisms explained the transition from acute to CLBP [97], [98]. In a subgroup of patients undergoing CLBP, signs of central sensitization (CS) have recently been reported. To clarify the efficacy of this modality, a few theories have been advanced. The theory of gate control indicates that TENS can prevent pain pathways from functioning in the dorsal horn of the spinal cord [99]. In addition, stimulation of the nervous system through transcutaneous electrodes is believed to modify pain perception and cause the release of endogenous analgesic substances such as endorphins [100], [101]. TENS is a relatively risk-free procedure with minimal side effects (e.g., patients with pacemakers, breastfeeding, sinus carotid use) and skin irritation is the most common side effect due to the TENS electrodes, which can be reduced by using non-irritant gels [98]. For training in the procedure, the patient needs to visit the hospital. Given the cost, this is an excellent value for money, if a small percentage of patients are able to live a productive life, back to their work without any hindrance, administer their own therapy at home, time-consuming, and avoid more expensive treatment [92].

\section{Hydrotherapy}

Hydrotherapy (Aquatic Exercise) for patients with LBP is an alternative form of treatment. Physiotherapy is now increasing with several specialties such as hydrotherapy used to treat the low back disorder for a few days [102]. While there is no specific problem or illness that can be established as the cause of chronic NLBP, hydrotherapy can help to relieve pain and improve physical well-being [103]. Chronic NLBP can be effectively treated with hydrotherapy, which is a natural alternative treatment option. The effectiveness of hydrotherapy would give subjects great gain in improving the QoL and decreasing disabilities [104]. Several authors conducted research on hydrotherapy for LBP. The effect of aquatic exercise on the treatment of CLBP is that it improves the QoL and disability of CLBP patients and is a better alternative to land-based exercises [105]. The properties of hydrotherapy reduce pain, decrease muscle spasm, improves joint range of motion, strengthen the weak muscles, enhances circulation, and improves balance and coordination when these exercises are performed in water [106]. In addition, the combination of buoyancy and water resistance properties makes the joint better mobility and eliminates limitations than on ground exercises [107]. The heat and floatability of water will act on thermal receptors and mechanoreceptors to block nociceptors and have a positive effect on spinal segments [108]. Hydrotherapy special properties minimize joint tension and the axial loading of the spine [109]. The buoyancy of the water allows a greater range of motion by supporting body weight, and changing the depth helps to develop resistance [110]. The aquatic environment enables the subject to perform activities that would be difficult or impossible on land, and it has been shown that the optimal exercise strength can be accomplished by controlling the speed of motion in water [111].

\section{Stress Management}

Physical and psychological stress, individual characteristics, and poor general health are known risk factors for LBP [112]. Stress, anxiety, and depression release cortisol through the endocrine, and nervous systems. Cortisol is a pulsatile stress hormone that is released in the bloodstream and is responsible for many catabolic processes in the body. Spinal stimulation can momentarily interrupt homeostatic processes in people with LBP. Chronic LBP may trigger physiological stress, resulting in the body releasing uncontrolled levels of cortisol [113]. Cortisol induces a catabolic state in the metabolism in stressful and painful conditions. People with chronic pain who are constantly stressed tend to have higher cortisol levels than healthy people [114]. In addition to pain sensitivity, elevated levels of cortisol associate with lower lumbar muscle power [115]. Therefore, cortisol has been used in studies involving people with LBP as a biochemical marker [115], [116]. Some studies indicate that physical activity can reduce stress and cortisol levels efficiently [117]. In individuals with chronic LBP, physical activity programs such as yoga [118], aquatic and stretching exercises have shown significant results in lowering cortisol levels [115]. Yoga exercises have thus been used as a conservative physical activity tool to decrease chronic LBP and stress [119], [120], [121]. Regular high-intensity aerobic exercise often raises the pain threshold and functional capacity in individuals with LBP, according to (Chatzitheodorou et al., 2007) [122], but does not display a decrease in serum cortisol levels.

\section{Kinesio Taping}

Kinesio Taping (KT) (Figure 2) is a commonly used trending therapy in patients with LBP. KT is 


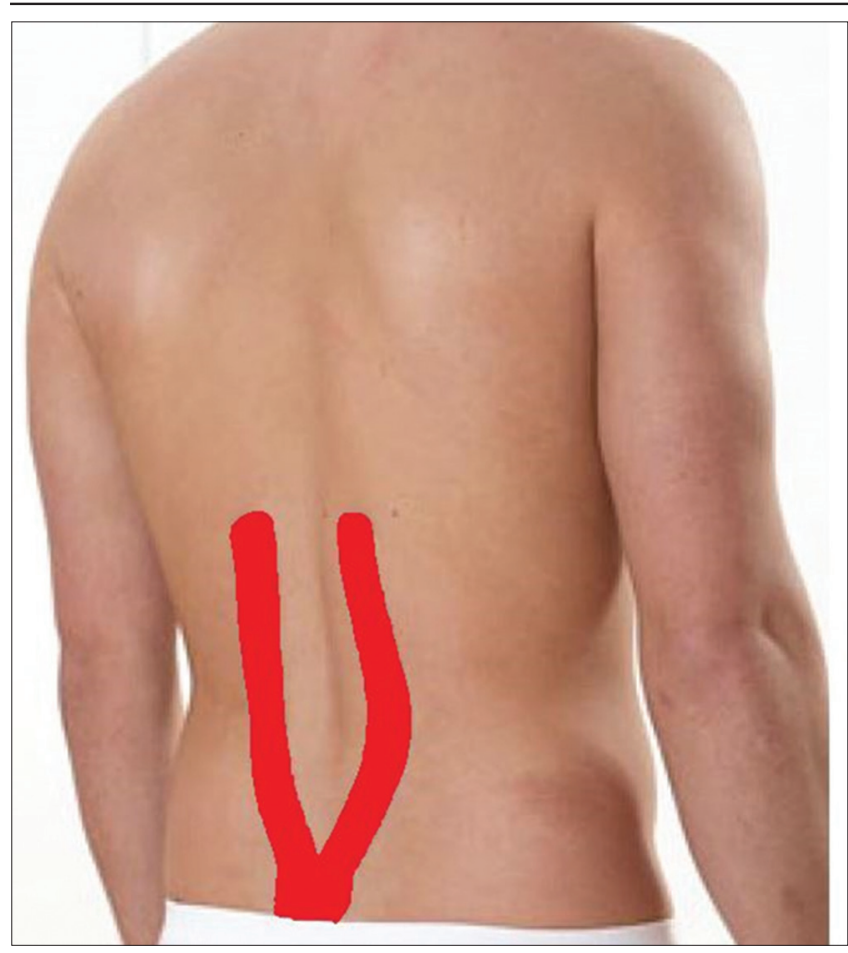

Figure 2: Indicates Kinesio taping for low back pain

thin and has elastic, skin-like mechanical properties to allow for a normal range of motion. In 1973, KT was developed by Kenzo Kase [123]. Kinesio taping has been suggested to provide cutaneous stretch stimulation, which may interfere with the transmission of mechanical and painful stimuli while also providing afferent stimuli, enhancing pain inhibitory mechanisms (gate control theory), and reducing pain [124], [125]. $\mathrm{KT}$ has beneficial effects on disability and functional activities in cases of LBP [126], [127], [128], [129]. Kase et al., 1996 [130], developed a theoretical structure to explain the immediate improvement in lumbar painrelated disability after using $\mathrm{KT}$. It was believed that when a muscle is hypertonic, it activates the transmission of information to the CNS by the Golgi receptors, where inhibitory motor neurons are stimulated, and that this process can therefore be triggered by stimulating the Golgi receptors by applying KT. KT increases the flexion range of motion in healthy subjects [131] and patients with LBP [127], [128], [131]. It has been shown that KT also increases the endurance of the back extensor muscles [127], [130].

\section{Footwear}

Paying attention to your footwear can help to prevent LBP. When standing or walking, the only part of the body that hits the ground is the feet. As a result, they have the ability to alter standing posture as well as the application of forces and gestures [132]. Footwear acts as a bond between the feet and the ground, enabling this connection to be altered. Different biomechanical interventions at the foot level have been utilized to improve LBP. Foot mechanics abnormality is closely related to irregular pelvic rotation during gait, leading to muscular dysfunction and lumbopelvic strain [133]. Different shoe inserts, insoles (viscoelastic or prefabricated), and custom-made foot orthotics were previously studied with reductions of LBP in specific populations with pronated standing foot posture [134], and female staff with static standing duties [135]. High heel shoes increase lumbar lordosis and compressive pressures on the lumbar lordosis, all of which lead to lumbar spondylosis. High heeled shoes have an effect on cervical and lumbar muscle activation and on postural control as well [136], Trunk muscle activation is necessary for balance and postural control. Trunk muscles provide support in situations where the body's balance is challenged [133], [135]. There is an increased disruption of body balance with high heeled shoes, and trunk muscle has to act more to preserve body balance. As health-care professionals, we should identify these threats and should be creating awareness among the living population.

\section{Conclusion}

Although the steady increasing burden of LBP specifically sub-acute and chronic cases represent the real challenge and of dire concern to various sector of population. The available literature still unable to adequately identify the core problems associated with high-risk patients, who may be vulnerable and become chronic once they failed to address the issues on time. To support this fact, there are no universal primary or secondary prevention and management measures have been demonstrated. Moreover, the risk of potential side effects should also be carefully weighted. In this regard, individual patient's preferences should be taken into account, before starting any available therapeutic interventions. In summary, based on the available literature the current comprehensive review provided a clarity and confidence in the diagnosis, assessment on the therapeutic interventions and their effectiveness for sub-acute and uprising chronic LBP cases. However, one has to realize that LBP is a difficult condition, which will continue to rise and affect millions of populations every year. In the coming years, it will continue to target aged people but also young technocrats that may make huge economic loss and compromise quality of life.

\section{Key recommendations}

Based on the various available diagnostic and therapeutic approaches, we attempt to provide the following practical, evidence-based recommendations. These recommendations are promising interventions 
not only to improve patient safety and reduce LBP but also to identify gap areas for future research in this field.

1. Most patients with acute or subacute low back pain should start with nonpharmacologic treatment, such as superficial heat or hot packs, acupuncture, massage, or spinal manipulation, because they will recover with time regardless of treatment.

2. Nonsteroidal anti-inflammatory medications (NSAIDs) or skeletal muscle relaxants should be utilized when pharmacologic treatment is sought.

3. For most patients with chronic low back pain, nonpharmacologic treatments such as spinal manipulation, cognitive behavioral therapy, posture correction, motor control exercise, therapeutic exercises, multidisciplinary rehabilitation, mindfulness-based stress reduction, acupuncture, yoga, tai chi, progressive relaxation, low-level laser therapy, or biofeedback should be used first.

4. NSAIDs should be used in patients with chronic low back pain who do not respond to nonpharmacologic treatment. Patients who do not respond to or tolerate NSAIDs should be considered for tramadol or duloxetine. Opioids should only be used if all other options have failed and the potential benefits exceed the hazards for a specific patient.

\section{References}

1. Vlaeyen, JW, Maher CG, Wiech K, Zundert JV, Meloto CB, Diatchenko $L$, et al. Low back pain. Nat Rev Dis Primers. 2018;4(1):52. https://doi.org/10.1038/s41572-018-0052-1 PMid:30546064

2. Refshauge KM, Maher CG. Low back pain investigations and prognosis: A review. Br J Sports Med. 2006;40(6):494-8. PMid:16720885

3. Dreisinger TE. Exercise in the management of chronic back pain. Ochsner J. 2014;14(1):101-7.

PMid:24688341

4. Gordon R, Bloxham SA. Systematic review of the effects of exercise and physical activity on non-specific chronic low back pain. Healthcare (Basel). 2016;4(2):22. https://doi.org/10.3390/ healthcare 4020022

PMid:27417610

5. Wu A, March L, Zheng X, Huang J, Wang X, Zhao J, et al. Global low back pain prevalence and years lived with disability from 1990 to 2017: Estimates from the global burden of disease study 2017. Ann Transl Med. 2020;8(6):299. https://doi.org/10.21037/ atm.2020.02.175

PMid:32355743

6. Last AR, Hulbert K. Chronic low back pain: Evaluation and management. Am Fam Physician. 2019;79(12):1067-74.

PMid:19530637

7. Kiran M, Suryawanshi SP, Gandhi N. Management of low back pain in computer users: A multidisciplinary approach. J Craniovertebr Junction Spine. 2012;3(1):7-10. https://doi. org/10.4103/0974-8237.110117

PMid:23741122

8. Wong AY, Karppinen A, Samartzis D. Low back pain in older adults: Risk factors, management options and future directions. Scoliosis Spinal Disord. 2017;12:14. https://doi.org/10.1186/ s13013-017-0121-3

PMid:28435906

9. de Souza IM, Sakaguchi TF, Yuan SL, Matsutani LA, EspíritoSanto AS, Pereira CA, et al. Prevalence of low back pain in the elderly population: A systematic review. Clinics (Sao Paulo). 2019;74:e789. https://doi.org/10.6061/clinics/2019/e789 PMid:31664424

10. Lim YZ, Chou L, Rebecca TM, Au, KL Seneviwickrama MD, Cicuttini FM, et al. People with low back pain want clear, consistent and personalised information on prognosis, treatment options and self-management strategies: A systematic review. J Physiother. 2019;65(3):124-35. https://doi.org/10.1016/j. jphys.2019.05.010

PMid:31227280

11. Fares MY, Fares J, Salhab HA, Khachfe HH, Bdeir A, Fares $Y$. Low back pain among weightlifting adolescents and young adults. Cureus. 2020;12(7):e9127. https://doi.org/10.7759/ cureus. 9127 PMid:32789068

12. Casazza BA. Diagnosis and treatment of acute low back pain. Am Fam Physician. 2012;85(4):343-50.

PMid:22335313

13. Masic I, Miokovic M, Muhamedagic B. Evidence based medicinenewapproaches and challenges. Acta Inform Med.2008;16(4):21925. https://doi.org/10.5455/aim.2008.16.219-225 PMid:24109156

14. Hartvigsen J, Lings S, Leboeuf-Yde C, Bakketeig L. Psychosocial factors at work in relation to low back pain and consequences of low back pain; a systematic, critical review of prospective cohort studies. Occup Environ Med. 2004;61(1):e2.

PMid: 14691283

15. Omoigui S. The biochemical origin of pain: The origin of all pain is inflammation and the inflammatory response. Part 2 of 3 -inflammatory profile of pain syndromes. Med Hypotheses. 2007;69(6):1169-78. https://doi.org/10.1016/j. mehy.2007.06.033

PMid:17728071

16. Battié MC, Videman T, Levalahti E, Gill K, Kaprio J. Heritability of low back pain and the role of disc degeneration. Pain 2007;131(3):272-80. https://doi.org/10.1016/j.pain.2007.01.0101 PMid: 17335977

17. Chan D, Song Y, Sham P, Kenneth M, Cheung C. Genetics of disc degeneration. Eur Spine J. 2006;15(3):317-25. https://doi. org/10.1007/s00586-006-0171-3 PMid:16819621

18. Amin RM, Andrade NS, Neuman BS. Lumbar disc herniation. Curr Rev Musculoskelet Med. 2017;10(4):507-16. https://doi. org/10.1007/s12178-017-9441-4 PMid:28980275

19. FoulkesT,WoodJN.Paingenes.PLoSGenet.2008;4(7):e1000086. https://doi.org/10.1371/journal.pgen.1000086 PMid: 18654615

20. Solovieva S, Leino-Arjas P, Saarela J, Luoma K, Raininko R, Riihimäki $\mathrm{H}$, et al. Possible association of interleukin 1 gene locus polymorphisms with low back pain. Pain. 2004;109(1- 2):8- 19. https://doi.org/10.1016/j.pain.2003.10.020 
PMid:15082121

21. Solovieva S, Pehkonen I, Kausto J, Miranda H, Shiri R, Kauppinen $\mathrm{T}$, et al. Development and validation of a job exposure matrix for physical risk factors in low back pain. PLoS One. 2012;7(11):e48680. https://doi.org/10.1371/journal. pone.0048680

PMid:23152793

22. Kędra A, Plandowska M, Kędra P, Czaprowski D. Non-specific low back pain: cross-sectional study of 11,423 children and youth and the association with the perception of heaviness in carrying of schoolbags. Peer J. 2021;9:e11220. https://doi. org/10.7717/peerj.11220

PMid:33986989

23. Verkerk K, Luijsterburg PA, Miedema HS, Pool-Goudzwaard A, Koes BW. Prognostic factors for recovery in chronic nonspecific low back pain: A systematic review. Phys Ther. 2012;92(9):1093- 108. https://doi.org/10.2522/ptj.20110388 PMid:22595238

24. Wang L, Yin Z, Zhang $Y$, Sun M, Yu Y, Lin Y, et al. Optimal acupuncture methods for nonspecific low back pain: A systematic review and bayesian network meta-analysis of randomized controlled trials. J Pain Res. 2021;14:1097-112. https://doi.org/10.2147/jpr.s310385

PMid:33907457

25. van Middelkoop M, Rubinstein SM, Verhagen AP, Ostelo RW, Koes BW, van Tulder MW, et al. Exercise therapy for chronic nonspecific low-back pain. Best Pract Res Clin Rheumatol. 2010;24(2):193-204. https://doi.org/10.1016/j.berh.2010.01.002 PMid:20227641

26. Macedo LG, Bostick GP, Maher CG. Exercise for prevention of recurrences of nonspecific low back pain. Phys Ther. 2013;93(12):1587-91. https://doi.org/10.2522/ptj.20120464 PMid:23813085

27. Chung JW, Zeng Y, Wong TK. Drug therapy for the treatment of chronic nonspecific low back pain: Systematic review and meta-analysis. Pain Physician. 2013;16(6):E685-704. https:// doi.org/10.36076/ppj.2013/16/e685

PMid:24284847

28. Jean-François C, Bernhard G, Bernd K, Frank P, Michael P, Susanne GS, et al. Non-specific low back pain. Dtsch Arztebl Int. 2017;114(51-52):883-90.

PMid:29321099

29. Chang CG, Candido KD, Knezevic NN. Digital subtraction angiography does not reliably prevent paraplegia associated with lumbar transforaminal epidural steroid injection. Pain Physician. 2012;15(6):515-23. https://doi.org/10.36076/ ppj.2012/15/515

PMid:23159970

30. Almeida DC, Kraychete DC. Low back pain-a diagnostic approach. Rev Dor. 2017;18(2):173-7. https://doi. org/10.5935/1806-0013.20170034

31. AIMazrou SH, Elliott RA, Knaggs RD, AlAujan SS. Costeffectiveness of pain management services for chronic low back pain: A systematic review of published studies. BMC Health Serv Res. 2020;20(1):194. https://doi.org/10.1186/ s12913-020-5013-1

PMid:32164720

32. Dale R, Stacey B. Multimodal treatment of chronic pain. Med Clin North Am. 2016;100(1):55-64. https://doi.org/10.1016/j. mcna.2015.08.012 PMid:26614719

33. Arnold JJ, Ehleringer SR. Is spinal manipulation an effective treatment for low back pain? Yes: evidence shows benefit in most patients. Am Fam Physician. 2012;85(8):756-8.

PMid:22534384
34. Gibbons P, Tehan P. Patient positioning and spinal locking for lumbar spine rotation manipulation. Manual Ther. 2001;6(3):130- 8. https://doi.org/10.1054/math.2001.0404 PMid:11527452

35. Rubinstein S, Middelkoop M, Assendelft W, Boer M, Tulder M. Benefits and harms of spinal manipulative therapy for the treatment of chronic low back pain: A systematic review and meta-analysis of randomised controlled trials. BMJ. 2019;364:1689. https://doi.org/10.1136/bmj.1689 PMid:30867144

36. Pickar J. Neurophysiological effects of spinal manipulation. Spine J. 2002;2(5):357-71.

PMid:14589467

37. Williams N, Hendry M, Lews R, Russel I, Westmoreland A, Wilkinson $\mathrm{C}$, et al. Psychological response in spinal manipulation (PRISM): A systematic review of psychological outcomes in randomised controlled trials. Complement Ther Med. 2007;15(4):271-83. https://doi.org/10.1016/j.ctim.2007.01.008 PMid:18054729

38. Gera C, Malik M, Kaur J, Saini M. A systematic review and meta-analysis on effect of spinal mobilization and manipulation on cardiovascular responses. Hong Kong Physiother J. 2020;40(2):75-87. https://doi.org/10.1142/s1013702520500122 PMid:33005072

39. Honore M, Leboeuf-Yd C, Gagey O. The regional effects of spinal manipulation on the pressure pain threshold in asymptomatic subjects: A systematic review. Chiropractic Manuel Ther. 2018;26:11. https://doi.org/10.1186/s12998-018-0181-3 PMid:29713457

40. Coronado R, Gay C, Bialosky J, Carnaby G, Bishop M, George S, et al. Changes in Pain sensitivity following spinal manipulation: A systematic review and meta-analysis. J Electromyograph Kinesiol. 2012;22(5):752-67. https://doi. org/10.1016/j.jelekin.2011.12.013

PMid:22296867

41. Coutaux A. Non-pharmacological treatments for pain relief: TENS and acupuncture. Joint Bone Spine. 2017;84(6):657-61. https://doi.org/10.1016/j.jbspin.2017.02.005

PMid:28219657

42. Manheimer E, White A, Berman B, Forys K, Ernst E. Meta-analysis: Acupuncture for low back pain. Ann Int Med. 2005;142(8):651- 63. https://doi.org/10.7326/0003-4819-142-8-200504190-00014 PMid:15838072

43. Chliessbach J, Klift EV, Arendt-Nielsen L, Curatolo $M$, Streitberger K. The effect of brief electrical and manual acupuncture stimulation on mechanical experimental pain. Pain. 2011;12(2):278-75. https://doi. org/10.1111/j.1526-4637.2010.01051.x

PMid:21276188

44. Li X, Wang R, Shi X, Su J, Pan Y, Tian J, et al. Reporting characteristics and quality of systematic reviews of acupuncture analgesia. Pain Pract. 2017;17(8):1066-74. https://doi. org/10.1111/papr.12555

PMid:28083991

45. Liu L, Skinner M, McDonough S, Mabire L, Baxter GD. Acupuncture for low back pain: An overview of systematic reviews. Evid Base Complement Alternat Med. 2015;2015:328196. https://doi.org/10.1155/2015/328196 PMid:25821485

46. Langevin HM, Schnyer R, MacPherson H, Davis R, Harris RE, Napadow V, et al. Manual and electrical needle stimulation in acupuncture research: Pitfalls and challenges of heterogeneity. J Altern Complement Med. 2015;21(3):113-28. https://doi. org/10.1089/acm.2014.0186

PMid:25710206 
47. Kwon Y, Kang M, Son S, Kim J, Lee Y, Han H, et al. Different frequencies of electroacupuncture modified the cellular activity of serotonergic neurons in brainstem. Am J Chin Med. 2000;28(3-4):435-41. https://doi.org/10.1142/s0192415x00000519 PMid:11154058

48. Han Z, Jiang Y, Wan Y, Wang Y, Chang JK, Han J. Endomorphin-1 mediates $2 \mathrm{~Hz}$ but not $100 \mathrm{~Hz}$ electroacupuncture analgesia in the rat. Neurosci Lett. 1999;274:75-8. https://doi.org/10.1016/ s0304-3940(99)00670-9 PMid:10553941

49. Janke EA, Collins A, Kozak AT. Overview of the relationship between pain and obesity: What do we know? Where do we go next? J Rehabil Res Dev. 2007;44(2):245-62. https://doi. org/10.1682/jrrd.2006.06.0060

PMid: 17551876

50. Brox JI, Storheim K, Holm I, Friis A, Reikerås O. Disability, pain, psychological factors and physical performance in healthy controls, patients with sub-acute and chronic low back pain: A case-control study. J Rehabil Med. 2005;37(2):95-9. https:// doi.org/10.1080/16501970410017738

PMid:15788344

51. Teichtahl AJ, Urquhart DM, Wang Y, Wluka AE, O'Sullivan $R$, Jones $G$, et al. Physical inactivity is associated with narrower lumbar intervertebral discs, high fat content of paraspinal muscles and low back pain and disability. Arthritis Res Ther. 2015;17(1):114. https://doi.org/10.1186/s13075-015-0629-y PMid:25947906

52. Steele J, Bruce-Low S, Smith D. A reappraisal of the deconditioning hypothesis in low back pain: Review of evidence from a triumvirate of research methods on specific lumbar extensor deconditioning. Curr Med Res Opin. 2014;30(5):865-911. https://doi.org/10.1185/ 03007995.2013.875465

\section{PMid:24328452}

53. McCaskey MA, Schuster-Amft C, Wirth B, Suica Z, de Bruin ED. Effects of proprioceptive exercises on pain and function in chronic neck-and low back pain rehabilitation: A systematic literature review. BMC Musculoskelet Disord. 2014;15:382. https://doi.org/10.1186/1471-2474-15-382

PMid:25409985

54. Hidalgo B, Detrembleur C, Hall T, Mahaudens P, Nielens H. The efficacy of manual therapy and exercise for different stages of non-specific low back pain: An update of systematic reviews. J Man Manip Ther. 2014;22(2):59-74. https://doi.org/10.1179/20 42618613y.0000000041

PMid:24976749

55. Standaert CJ, Friedly J, Erwin MW, Lee MJ, Rechtine G, Henrikson NB, et al. Comparative effectiveness of exercise, acupuncture, and spinal manipulation for low back pain. Spine. 2011;36(21):S120-30. https://doi.org/10.1097/ brs.0b013e31822ef878

PMid:21952184

56. van Middelkoop M, Rubinstein SM, Kuijpers $T$, Verhagen $A P$, Ostelo R, Koes BW, et al. Asystematic review on the effectiveness of physical and rehabilitation interventions for chronic nonspecific low back pain. Eur Spine J. 2011;20(1):19- 39. https:// doi.org/10.1007/s00586-010-1518-3

PMid:20640863

57. Chambers H. Physiotherapy and lumbar facet joint injections as a combination treatment for chronic low back pain. A narrative review of lumbar facet joint injections, lumbar spinal mobilizations, soft tissue massage and lower back mobility exercises. Musculoskeletal Care. 2013;11(2):106-20. https:// doi.org/10.1002/msc. 1045

PMid:23468052

58. Furlan AD, Yazdi F, Tsertsvadze A, Gross A, Van Tulder M,
Santaguida L, et al. Complementary and alternative therapies for back pain II. Evid Rep Technol Assess. 2010;194:1-764.

59. Zdziarski LA, Wasser JG, Vincent HK. Chronic pain management in the obese patient: A focused review of key challenges and potential exercise solutions. J Pain Res. 2015;8:63-77. https:// doi.org/10.2147/jpr.s55360

PMid:25709495

60. Vincent HK, George SZ, Seay AN, Vincent KR, Hurley RW. Resistance exercise, disability, and pain catastrophizing in obese adults with back pain. Med Sci Sports Exerc. 2014;46:1693-701. https://doi.org/10.1249/mss.0000000000000294

PMid:25133997

61. Palstam A, Larsson A, Löfgren M, Ernberg M, Bjersing J, Bileviciute-Ljungar I, et al. Decrease of fear avoidance beliefs following person-centered progressive resistance exercise contributes to reduced pain disability in women with fibromyalgia: Secondary exploratory analyses from a randomized controlled trial. Arthritis Res Ther. 2016;18(1):116. https://doi.org/10.1186/ s13075-016-1007-0

PMid:27209068

62. Valencia WM, Stoutenberg M, Florez H. Weight loss and physical activity for disease prevention in obese older adults: An important role for lifestyle management. Curr Diab Rep. 2014;14(10):539. https://doi.org/10.1007/s11892-014-0539-4

PMid:25183491

63. Baena-Beato PÁ, Artero EG, Arroyo-Morales M, RoblesFuentes A, Gatto-Cardia MC, Delgado-Fernández M. Aquatic therapy improves pain, disability, quality of life, body composition and fitness in sedentary adults with chronic low back 478 pain. A controlled clinical trial. Clin Rehabil. 2014;28(4):350-60. https://doi.org/10.1177/0269215513504943

PMid:24177712

64. Kell RT, Asmundson GJ. A comparison of two forms of periodized exercise rehabilitation programs in the management of chronic nonspecific low-back pain. J Strength Cond Res Natl Strength Cond Assoc. 2009;23(2):513-23. https://doi.org/10.1519/ jsc.0b013e3181918a6e

PMid: 19209082

65. Deyo RA, Weinstein JN. Low back pain. N Engl J Med. 2001;344(5):363-70.

PMid:11172169

66. Chou R. In the clinic Low back pain. Ann Intern Med. 2014;160(11):ITC6-1. https://doi. org/10.7326/0003-4819-160-11-201406030-01006

PMid:25009837

67. Roelofs PD, Deyo RA, Koes BW, Scholten RJ, van Tulder MW. Non-steroidal anti-inflammatory drugs for low back pain. Cochrane Database Syst Rev. 2008;1:CD000396. https://doi. org/10.1002/14651858.cd000396.pub3

PMid: 18253976

68. Chou R, Qaseem A, Snow V, Casey D, Cross JT, Shekelle P, et al. Diagnosis and treatment of low back pain: A joint clinical practice guideline from the American college of physicians and the American pain society. Ann Intern Med. 2007;147(7):478. https://doi.org/10.7326/0003-4819-147-7-200710020-00006 PMid:17909209

69. van Tulder M, Becker A, Bekkering T, Breen A, Gil del Real MT, Hutchinson A, et al. Chapter 3 European guidelines for the management of acute nonspecific low back pain in primary care. Eur Spine J. 2016;15(2):s169-91. https://doi.org/10.1007/ s00586-006-1071-2

PMid: 16550447

70. Pereira S, Power C. Sedentary behaviours in mid-adulthood and subsequent body mass index. PLoS One. $2013 \mathrm{https} / / / \mathrm{doi}$. org/10.1371/journal.pone.0065791 


\section{PMid:23762427}

71. Aissaoui R, Lacoste M, Dansereau J. Analysis of sliding and pressure distribution during a repositioning of persons in a simulator chair. IEEE Trans Neural Sys Rehabil Eng. 2001;9(2):215-24. https://doi.org/10.1109/7333.928581

PMid:11474974

72. Schneider R. Pantograph for tilting trains. In: IEEE Current Collections for High-Speed Trains Seminar. United States: IEEE; 1998. https://doi.org/10.1049/ic:19981001

73. Neville L. The Fundamental Principles of Seating and Positioning in Children and Young People with Physical Disabilities. Coleraine: University of Ulster; 2005.

74. Seperson S. Elder Care and Service Learning: A Handbook. Charlotte: Information Age Publishing; 2008.

75. Browder DA, Childs JD, Cleland JA, Fritz JM. Effectiveness of an extension-oriented treatment approach in a subgroup of subjects with low back pain: A randomized clinical trial. Phys Ther. 2007;87(12):1608-18. https://doi.org/10.2522/ ptj.20060297 PMid:17895350

76. Nelson-Wong E, Howarth S, Callaghan J. Acute biomechanical responses to a prolonged standing exposure in a simulated occupational setting. Ergonomics. 2010;53(9):1117-28. https:// doi.org/10.1080/00140139.2010.500400

PMid:20737337

77. Rahim AH, Omar AR, Halim I, Saman AM, Alina M, Othman I, et al. Analysis of muscle fatigue associated with prolonged standing tasks in manufacturing industry. In: International Conference on Science and Social Research (CSSR). Malaysia: Kuala Lumpur; 2010. p. 711-6. https://doi.org/10.1109/cssr.2010.5773875

78. Zander JE, King PM, Ezenwa BN. Influence of flooring conditions on lower leg volume following prolonged standing. Int J Ind Ergonom. 2004;34(4):279-88. https://doi.org/10.1016/j. ergon.2004.04.014

79. Garcìa AN, Costa L, Hancock MJ, de Souza FS, de Oliveira Gomes GV, de Almeida MO, et al. McKenzie method of mechanical diagnosis and therapy was slightly more effective than placebo for pain, but not for disability, in patients with chronic non-specific low back pain: A randomised placebocontrolled trial with short-and longer-term follow-up. $\mathrm{Br} \mathrm{J}$ Sports Med. 2018;52(9):594-600. https://doi.org/10.1136/ bjsports-2016-097327

PMid:28701365

80. Korovessis $P$, Stamatakis M, Baikousis A, Korovessis P Segmental roentgenographic analysis of vertebral inclination on sagittal plane in asymptomatic vs chronic low back pain patients. J Spinal Disord. 1998;12(2):131-7. https://doi. org/10.1097/00002517-199904000-00009

81. Qaseem A, Wilt TJ, McLean RM. Non-invasive treatments for acute, subacute, and chronic low back pain: A clinical practice guideline from the American college of physicians. Ann Intern Med. 2017;166(7):514-30. https://doi.org/10.7326/m16-2367 PMid:28192789

82. National Institute for Health and Care Excellence. Clinical Guidelines. Low Back Pain and Sciatica in Over 16s: Assessment and Management. National Guideline Centre (UK). London: National Institute for Health and Care Excellence; 2016. https:// doi.org/10.1093/ww/9780199540884.013.u13729

83. Wang XQ, Zheng JJ, Yu ZW, Bi X, Lou SJ, Liu J, et al. A metaanalysis of core stability exercise versus general exercise for chronic low back pain. PLoS One. 2012;7(12):e52082. https:// doi.org/10.1371/journal.pone.0052082

PMid:23284879

84. Searle A, Spink M, Ho A, Chuter V. Exercise interventions for the treatment of chronic low back pain: $A$ systematic review and meta-analysis of randomised controlled trials. Clin Rehabil. 2015;29(12):1155-67. https://doi. org/10.1177/0269215515570379

PMid:25681408

85. Jeong UC, Sim JH, Kim CY, Hwang-Bo G, Nam CW. The effect of gluteus muscle strengthening exercise and lumbar stabilization exercise on lumbar muscle strength and balance in chronic low back pain patients. J Phys Ther Sci. 2015;27(12):3813-6. https://doi.org/10.1589/jpts.27.3813

PMid:26834359

86. Ferreira ML, Ferreira $\mathrm{PH}$, Latimer J, Herbert RD, Hodges PW, Jennings MD, et al. Comparison of general exercise, motor control exercise and spinal manipulative therapy for chronic low back pain: A randomized trial. Pain. 2007;131(1-2):31-7. https:// doi.org/10.1016/j.pain.2006.12.008

PMid:17250965

87. Panjabi MM. The stabilizing system of the spine. Part I. Function, dysfunction, adaptation, and enhancement. J Spinal Disord. 1992;5(4):383-9. https://doi. org/10.1097/00002517-199212000-00001

PMid:1490034

88. van Dieen JH, Cholewicki J, Radebold A. Trunk muscle recruitment patterns in patients with low back pain enhance the stability of the lumbar spine. Spine. 2003;28(8):834-41. https:// doi.org/10.1097/01.brs.0000058939.51147.55

PMid:12698129

89. Ferreira G, Costa LM, Stein A, Hartvigsen J, Buchbinder R, Maher CG. Tackling low back pain in Brazil: A wake-up call. Braz J Phys Ther. 2019;23(3):189-95. https://doi.org/10.1016/j. bjpt.2018.10.001

PMid:30337255

90. Coste J, Venot A. An epidemiologic approach to drug prescribing quality assessment: A study in primary care practice inFrance. Med Care. 1999;37(12):1294-307. https://doi. org/10.1097/00005650-199912000-00012

PMid:10599610

91. Cherkin DC, Wheeler KJ, Barlow W, Deyo RA. Medication use for low back pain in primary care. Spine (Phila Pa 1976). 1998;23(5):607-14. https://doi. org/10.1097/00007632-199803010-00015 PMid:9530793

92. Khadilkar A, Milne S, Brosseau L, Wells G, Tugwell P, Robinson $\mathrm{V}$, et al. Transcutaneous electrical nerve stimulation for the treatment of chronic low back pain: A systematic review. Spine (Phila Pa 1976). 2005;30(23):2657-66. https://doi. org/10.1097/01.brs.0000188189.21202.0f

PMid:16319752

93. French SD, Cameron M, Walker BF, Reggars JW, Esterman AJ. A cochrane review of superficial heat or cold for low back pain. Spine (Phila Pa 1976). 2003;31(9):998-1006. https://doi. org/10.1097/01.brs.0000214881.10814.64 PMid:16641776

94. Levin MF, Hui-Chan CW. Conventional and acupuncturelike transcutaneous electrical nerve stimulation excite similar afferent fibers. Arch Phys Med Rehabil. 1993;74(1):54-60. PMid:8420521

95. Radhakrishnan $R$, Sluka KA. Deep tissue afferents, but not cutaneous afferents, mediate transcutaneous electrical nerve stimulation-induced anti-hyperalgesia. J Pain. 2005;6(10):673- 80. https://doi.org/10.1016/j.jpain.2005.06.001 PMid:16202960

96. Graven-Nielsen T, Arendt-Nielsen L. Assessment of mechanisms in localized and widespread musculoskeletal pain. Nat Rev Rheumatol. 2010;6(10):599-606. https://doi.org/10.1038/ nrrheum.2010.107

PMid:20664523 
97. O'Neill S, Manniche C, Graven-Nielsen T, Arendt-Nielsen L. Generalized deep-tissue hyperalgesia in patients with chronic low-back pain. Eur J Pain. 2007;11(4):415-20. https://doi. org/10.1016/j.ejpain.2006.05.009 PMid:16815054

98. Jarzem PF, Harvey EJ, Arcaro N, Kaczorowski J. Transcutaneous electrical nerve stimulation [TENS] for chronic low back pain. J Musculoskelet Pain. 2005;13(2):3-9. https://doi.org/10.1300/ j094v13n02_02

99. Melzack R, Wall PD. Pain mechanisms: A new theory. Science. 1995;150(3699):971-7.

PMid:5320816

100. Hughes GS Jr., Lichstein PR, Whitlock D, Harker C. Response of plasma beta-endorphins to transcutaneous electrical nerve stimulation in healthy subjects. Phys Ther. 1984;64(7):1062-6. https://doi.org/10.1093/ptj/64.7.1062 PMid:6330773

101. Mckenzie R. The Lumbar Spine Mechanical Diagnosis and Therapy. $2^{\text {nd }}$ ed., Vol. 1. Paraparaumu, New Zealand: Spinal Publications New Zealand Ltd.; 2003.

102. Levangie PK, Norkin CC. Joint Structure and Function. $5^{\text {th }}$ ed. Philadelphia, PA: FA Davis; 2011.

103. Chaitow L. Hydrotherapy. Water Therapy for Health and Beauty. Boston, MA: Element Books; 1996.

104. Dundar U, Solak O, Yigit I, Evcik D, Kavuncu V. Clinical effectiveness of aquatic exercise to treat chronic low back pain. Spine. 2009;34(14):1436-40. https://doi.org/10.1097/ brs.0b013e3181a79618

PMid:19525833

105. Geytenbeek J. Evidence for effective hydrotherapy. Physiotherapy. 2005;88(9):514-29. https://doi.org/10.1016/ s0031-9406(05)60134-4

106. Ariyoshi M, Sonoda K, Nagata K, Mashima T, Zenmyo M, Paku C, et al. Efficacy of aquatic exercises for patients with low-back pain. The Kurume Med J. 1998;46(2):91-6. https://doi. org/10.2739/kurumemedj.46.91

PMid:10410527

107. Castro-Sanchez AM, Guillermo A, Lara-Palomo I, SaavedraHernández $M$, Arroyo-Morales $M$, Moreno-Lorenzo $C$. Hydrotherapy for the treatment of pain in people with multiple sclerosis: A randomized controlled trial. Evid Based Complement Alternat Med. 2012;2014:473963.

108. Camilotti BM, RodackiAL, Israel VL, Fowler NE. Stature recovery after sitting on land and in water. Man Ther. 2009;14(6):685-9. https://doi.org/10.1016/j.math.2009.03.007 PMid:19467912

109. Skelton DA, Dinan SM. Exercise for falls management: Rationale for an exercise programme aimed at reducing postural instability. Physiother Theor Pract. 1999;15(2):105-20. https:// doi.org/10.1080/095939899307801

110. Moseley L. Combined physiotherapy and education is efficacious for chronic low back pain. Aust J Physiother. 2002;48(4):297- 302. https://doi.org/10.1016/s0004-9514(14)60169-0 PMid:12443524

111. Oliveira RF, Fandim JV, Fioratti I, Fernandes LG, Saragiotto BT, Costa LO. The contemporary management of nonspecific lower back pain. Pain Manage. 2019;9(5):475-82. https://doi. org/10.2217/pmt-2019-0016

PMid:31452452

112. Padayachy K, Vawda HM, Shaik J, McCarthy PW. The immediate effect of low back manipulation on serum cortisol levels in adult males with mechanical low back pain. Clin Chiropractic. 2010;13(4):246-52. https://doi.org/10.1016/j.clch.2010.05.002

113. Eichler J, Rachinger-Adam B, Kraft E, Azad SC. Efficacy of biofeedback in patients with chronic low back pain: Impact on pain intensity, psychological factors and stress markers. Schmerz. 2019;33(6):539-48. https://doi.org/10.1007/ s00482-019-0393-z

PMid:31346772

114. Castro JB, Lima VP, Santos AO, Da Silva GC, De Oliveira JG, Da Silva JN, et al. Correlation analysis between biochemical markers, pain perception, low back functional disability, and muscle strength in postmenopausal women with low back pain. J Phys Educ Sport. 2020;20(1):24-30.

115. Paungmali A, Joseph LH, Punturee K, Sitilertpisan $P$, Pirunsan U, Uthaikhup S. Immediate effects of core stabilization exercise on $\beta$-endorphin and cortisol levels among patients with chronic nonspecific low back pain: A randomized crossover design. J. Manipulative Physiol. Ther. 2018;41(3):181-8. https:// doi.org/10.1016/j.jmpt.2018.01.002

PMid:29459120

116. Sugano A, Nomura T. Influence of water exercise and land stretching on salivary cortisol concentrations and anxiety in chronic low back pain patients. J Physiol Anthropol Appl Hum Sci. 2000;19(4):175-80. https://doi.org/10.2114/jpa.19.175 PMid:11037691

117. Cho HK, Moon W, Kim J. Effects of yoga on stress and inflammatory factors in patients with chronic low back pain: A non-randomized controlled study. Eur J Integr Med. 2015;7(2):118-23. https://doi.org/10.1016/j.eujim.2014.10.008

118. Coelho CM, Lessa TT, Carvalho RM, Coelho LA, da Silva Scari R, da Silva Fernandes N, et al. Quality of life in female practitioners of Hatha Yoga. Motriz Rev Ed Fisica. 2011;17(1):33-8.

119. Tekur $P$, Chametcha $S$, Hongasandra RN, Raghuram N. Effect of yoga on quality of life of CLBP patients: A randomized control study. Int J Yoga. 2010;3(1):10-7. https://doi. org/10.4103/0973-6131.66773

PMid:20948896

120. Haldavnekar RV, Tekur P, Nagarathna R, Nagendra HR. Effect of yogic colon cleansing (laghu sankhaprakshalana kriya) on pain, spinal flexibility, disability and state anxiety in chronic low back pain. Int J Yoga. 2014;7(2):111-9. https://doi. org/10.4103/0973-6131.133884

PMid:25035620

121. Chatzitheodorou D, Kabitsis C, Malliou P, Mougios V. A pilot study of the effects of high-intensity aerobic exercise versus passive interventions on pain, disability, psychological strain, and serum cortisol concentrations in people with chronic low back pain. Phys Ther. 2007;87(3):304-12. https://doi.org/10.2522/ptj.20060080 PMid: 17284546

122. Bicici S, Karatas N, Baltaci G. Effect of athletic taping and kinesiotaping ${ }^{\circledR}$ on measurements of functional performance in basketball players with chronic inversion ankle sprains. Int $J$ Sports Phys Ther. 2012;7(2):154-66.

PMid:22530190

123. Paoloni M, Bernetti A, Fratocchi G, Mangone M, Parrinello L, De Pilar Cooper M, et al. Kinesio taping applied to lumbar muscles influences clinical and electromyographic characteristics in chronic low back pain patients. Eur J Phys Rehabil Med. 2011;47(2):237-44 PMid:21430611

124. DeLeo JA. Basic science of pain. J Bone Joint Surg Am. 2006;88(2):58-62.

PMid: 16595445

125. Kelle B, Güzel R, Sakallı H. The effect of Kinesio taping application for acute non-specific low back pain: A randomized controlled clinical trial. Clin Rehabil. 2016;30(10):997-1003. https://doi.org/10.1177/0269215515603218 PMid:26316553

126. Castro-Sánchez AM, Lara-Palomo IC, Matarán-Peñarrocha GA, 

Fernández-Sánchez $\quad \mathrm{M}, \quad$ Sánchez-Labraca $\mathrm{N}$,
Arroyo- Morales M. Kinesio Taping reduces disability and pain slightly in chronic non-specific low back pain: A randomised trial. J Physiother. 2011;58(2):89-95. https://doi.org/10.1016/ s1836-9553(12)70088-7
PMid:22613238
127. Hwang-Bo G, Lee JH. Effects of kinesio taping in a physical therapist with acute low back pain due to patient handling: A case report. Int J Occup Med Environ Health. 2011;24(3):320- 3. https://doi.org/10.2478/s13382-011-0029-8

\section{PMid:21845524}

128. Inanoglu D, Baltacı G. Effects of different taping techniques on quality of life and pain in low back pain patients without any neurological deficits. J Exerc Ther Rehabil. 2014;1(1):26-34.

129. Kase K, Tatsuyuki H, Tomoko O. Development of kinesio tape. Kinesio taping perfect manual. Kinesio Taping Assoc. 1996;6:117-8.

130. Yoshida A, Kahanov L. The effect of kinesio taping on lower trunk range of motions. Res Sports Med. 2007;15(2):103-12. https://doi.org/10.1080/15438620701405206

PMid:17578750

131. AlBahel F, Hafez RA, Zakaria RA, Al-Ahaideb A, Buragadda S, Melam RG. Kinesio taping for the treatment of mechanical low back pain. World Appl Sci J. 2013;22(1):78-84.

132. Hagen L, Hebert JJ, Dekanich J, Koppenhaver S. The effect of elastic therapeutic taping on back extensor muscle endurance in patients with low back pain: A randomized, controlled, crossover trial. J Orthop Sports Phys Ther. 2015;45(3):215-9. https://doi. org/10.2519/jospt.2015.5177

PMid:25679343

133. Castro-Mendez A, Munuera PV, Albornoz-Cabello M. The short-term effect of custom-made foot orthoses in subjects with excessive foot pronation and lower back pain: A randomized, double-blinded, clinical trial. Prosthet Orthot Int. 2013;37(5):384- 90. https://doi.org/10.1177/0309364612471370 PMid:23327838

134. Almeida J, Pastre C, Padovani C, Martins R. Comparison of plantar pressure and musculoskeletal symptoms with the use of custom and prefabricated insoles in the work environment. Rev Bras Fisioter. 2009;13:542-8.

135. Park K, Kim Y, Chung Y, Hwang S. Effects of the height of shoe heels on muscle activation of cervical and lumbar spine in healthy women. J Phys Ther Sci. 2016;28(3):956-9. https://doi. org/10.1589/jpts.28.956

PMid:27134392

136. Sun D, Gu Y, Mei Q, Shao Y, Sun J, Fernandez J. Effect of heel heights on female postural control during standing on a dynamic support surface with sinusoidal oscillations. J Mot Behav. 2017;49(3):281-7. https://doi. org/10.1080/00222895.2016.1191 423

PMid:27588676 